\title{
Nanoscale $\mathrm{TiO}_{2}$ nanotubes govern the biological behavior of human glioma and osteosarcoma cells
}

\author{
This article was published in the following Dove Press journal: \\ International Journal of Nanomedicine \\ 25 March 2015 \\ Number of times this article has been viewed
}

Ang Tian,' Xiaofei Qin, ${ }^{2}$

Anhua Wu, ${ }^{2}$ Hangzhou Zhang, ${ }^{3}$

Quan Xu, ${ }^{4}$ Deguang Xing, ${ }^{2}$

He Yang,' Bo Qiu, ${ }^{2}$

Xiangxin Xue,' Dongyong

Zhang, ${ }^{2}$ Chenbo Dong ${ }^{5}$

'Liaoning Provincial Universities Key Laboratory of Boron Resource Ecological Utilization Technology and Boron Materials, Northeastern University, ${ }^{2}$ Department of

Neurosurgery, The First Affiliated Hospital of China Medical University, ${ }^{3}$ Department of Sports Medicine and Joint Surgery, The First Affiliated Hospital of China Medical University, Shenyang, ${ }^{4}$ Institute of New Energy, State Key Laboratory of Heavy Oil Processing, China University of Petroleum, Beijing, People's Republic of China; ${ }^{5}$ Department of Civil and Environmental Engineering, Rice University, Houston, TX, USA

Correspondence: Xiangxin Xue Liaoning Provincial Universities Key Laboratory of Boron Resource Ecological Utilization Technology and Boron Materials, Northeastern University, Lane II, 3 Wenhua Road, Heping District, Shenyang II0819, People's Republic of China

Tel +860248368 737I

Fax +8602423906316

Email xuexx@mail.neu.edu.cn

Anhua Wu

Department of Neurosurgery, The First Affiliated Hospital of China Medical University, 155 North Nanjing Street, Heping District, Shenyang I I000I. People's Republic of China

Tel +86024 235। 7484

Fax +860248328 330I

Email wuanhua@yahoo.com
Abstract: Cells respond to their surroundings through an interactive adhesion process that has direct effects on cell proliferation and migration. This research was designed to investigate the effects of $\mathrm{TiO}_{2}$ nanotubes with different topographies and structures on the biological behavior of cultured cells. The results demonstrated that the nanotube diameter, rather than the crystalline structure of the coatings, was a major factor for the biological behavior of the cultured cells. The optimal diameter of the nanotubes was $20 \mathrm{~nm}$ for cell adhesion, migration, and proliferation in both glioma and osteosarcoma cells. The expression levels of vitronectin and phosphor-focal adhesion kinase were affected by the nanotube diameter; therefore, it is proposed that the responses of vitronectin and phosphor-focal adhesion kinase to the nanotube could modulate cell fate. In addition, the geometry and size of the nanotube coating could regulate the degree of expression of acetylated $\alpha$-tubulin, thus indirectly modulating cell migration behavior. Moreover, the expression levels of apoptosis-associated proteins were influenced by the topography. In conclusion, a nanotube diameter of $20 \mathrm{~nm}$ was the critical threshold that upregulated the expression level of Bcl-2 and obviously decreased the expression levels of Bax and caspase-3. This information will be useful for future biomedical and clinical applications.

Keywords: nanotopography, migration, proliferation, adhesion, apoptosis

\section{Introduction}

The cell-material surface interaction is one of most important factors for cell adhesion, and plays an important role in regulating cell communication and a series of cell behaviors, including cellular growth, migration, proliferation, differentiation, and apoptosis. ${ }^{1-3}$ During cellular adhesion, cells alternately interact with materials via surface receptors that transduce external chemical signals or mechanical stimulation and eventually regulate the expression of specific genes and proteins. ${ }^{4,5}$ Simultaneously, the transfer of internal activities relies greatly on external materials. ${ }^{6}$ This complicated process is commonly referred to as bidirectional signal transduction, in which cellular adhesion and material surface properties correlate intimately. In tissue engineering, the surface properties of biological materials usually impose crucial impacts on cell culture, ${ }^{7}$ healing of wounds, ${ }^{8}$ and tissue restoration and reconstruction. ${ }^{9}$ Specifically, cell behavior can be manipulated by altering their material properties, including chemical, ${ }^{10,11}$ nonmechanical physical, ${ }^{12,13}$ and mechanical properties in vitro. ${ }^{14}$ Nanopatternization has been applied effectively to regulate the nonmechanical and physical properties of materials, such as topological structure, ${ }^{15}$ roughness, ${ }^{16}$ geometric properties, ${ }^{17}$ and surface energy. ${ }^{18}$ It has been demonstrated that it is important to unveil the mechanisms of cell-material interactions on nanopatterned surfaces at the biomolecular level. ${ }^{5}$ 
Titanium and its compounds $\left(\mathrm{TiO}_{2}\right)$ have been used widely in clinical applications, mainly due to their favorable mechanical properties and biocompatibilities. ${ }^{19-23}$ For instance, $\mathrm{TiO}_{2}$ nanotube arrays with specific diameters and lengths have been confirmed to improve the biological functioning of osteoblasts. ${ }^{20}$ In addition, $\mathrm{TiO}_{2}$ nanotube arrays have been demonstrated as a promising supporting electrode material in the construction of electrochemical glucose biosensors for medical and clinical applications. ${ }^{22,23}$ Previous studies have reported that the $\mathrm{TiO}_{2}$ nanotube array coating can regulate cellular adhesion structures, ${ }^{19,20}$ cell proliferation rates, and cell differentiation behavior. ${ }^{21}$ In particular, changing the nanotube diameter can affect cell behavior. For instance, the biological behavior of mesenchymal stem cells on a nanotube surface is size-dependent. ${ }^{24}$ A $15-20 \mathrm{~nm}$ nanotube coating has been shown to promote cellular adhesion, proliferation, migration, and differentiation to a large extent, while a $100 \mathrm{~nm}$ nanotube coating can lead to significant cell apoptosis. Such a correlation can be identified as a prevalent property of cross populations. ${ }^{5,21,24,25}$ However, there is still no deep understanding regarding the mechanisms involving multiple interactions between cells and materials or the relevant cellular response under certain conditions. Therefore, further studies are needed. ${ }^{26}$

Gliomas are the most common malignant tumors of the central nervous system, ${ }^{27}$ with a high postoperative recurrence rate and a poor prognosis. ${ }^{28}$ Additionally, due to the specific location as an intracranial tumor and the inevitable damage that occurs during surgery, survivors tend to have neurological deficits and a poor quality of life. Therefore, it is necessary to investigate the biological behaviors and underlying cellular mechanisms of glioma cells on nanotubes, which could provide insights for further fundamental research and clinical applications. Our previous study demonstrated that the biological behavior of rat C6 glioma cells cultured on nanotube coatings depended heavily on the nanotube diameter. ${ }^{25}$ Moreover, it has been shown that human MG-63 osteoblasts have a good differentiation capacity on micro/nanotextured topographies. ${ }^{29}$ However, to the best of our knowledge, the mechanisms by which the $\mathrm{TiO}_{2}$ nanotube affects the behavior of U87 and MG-63 cells have been rarely studied. Therefore, to deepen our understanding of how $\mathrm{TiO}_{2}$ nanotube arrays modulate cell behavior at the cell-nanotube interface, we investigated the mutual interactive mechanisms between nanotubes with different diameters and the behavior of U87 human glioblastoma cells and MG-63 osteosarcoma cells. The results of this study will provide insight regarding the ubiquitous effects of nanotube diameter on certain behaviors in some types of tumor cells.

\section{Materials and methods Fabrication of $\mathrm{TiO}_{2}$ nanotubes with different diameters}

A pure titanium plate (purity 99.5\%) $2 \mathrm{~cm}$ in diameter and $0.5 \mathrm{~mm}$ in thickness was polished by abrasive paper to obtain a smooth and flat surface, followed by washed in acetone and ultrasonication for 30 minutes to remove the stains on the surface of the titanium. Finally, the plate was washed three times with deionized water before drying in a stream of nitrogen gas. In this study, the $\mathrm{TiO}_{2}$ nanotube coating was fabricated at room temperature by a two-step anodization process. ${ }^{30}$ First, an ethanediol solution containing $0.5 \mathrm{wt} \%$ ammonium fluoride was used as the electrolyte (W1) required in the first step of anodization. Next, the titanium plate was anodized under a constant voltage of $60 \mathrm{~V}$ for 2 hours with the platinum sheet as the cathode. Next, the sample was cleaned in diluted hydrochloric acid and dried in a stream of nitrogen gas for the next anodization step. An ethanediol solution containing $0.5 \mathrm{wt} \%$ ammonium fluoride and $2 \mathrm{vol} \%$ hydrofluoric acid was used as the electrolyte (W2), the sample was anodized at the electrolyte (W2) under constant voltage (ranging from $20 \mathrm{~V}$ to $60 \mathrm{~V}$ to control the nanotube diameter in this study) for 4 hours; the specimen was then washed with distilled water and dried in a stream of nitrogen gas for the subsequent cell experiment. Finally, the $\mathrm{TiO}_{2}$ nanotube coating was thermally treated in air at $450^{\circ} \mathrm{C}$ at a heating rate of $5^{\circ} \mathrm{C}$ per minute.

\section{Surface characterization of $\mathrm{TiO}_{2}$ nanotube coating}

A field emission scanning electron microscope (SU8010, Hitachi, Tokyo, Japan) was used to observe the morphology of the $\mathrm{TiO}_{2}$ nanotube coatings. X-ray diffraction $(\mathrm{D} / \mathrm{max}$ 2400 , Rigaku, Tokyo, Japan) was used to identify the crystalline structure, using $\mathrm{Cu} \mathrm{K} \alpha$ incident radiation, a tube voltage of $40 \mathrm{kV}$, a current of $30 \mathrm{~mA}$, a scanning angle ranging from $20^{\circ}$ to $80^{\circ}$, and a scanning rate of $5^{\circ}$ per minute. A camera and microscope were used to measure the contact angle $\theta$ by analyzing the drop shape, ${ }^{25}$ and the investigation was carried out with an accuracy of $\pm 1^{\circ}$ at a temperature of $25^{\circ} \mathrm{C}$.

\section{Cell culture}

Titanium and titanium-coated nanotubes were sterilized using $75 \%$ alcohol, washed three times with sterile deionized water, irradiated with ultraviolet light for 3 hours on the back and 6 hours on the front, and then transferred to a 
6-well plate. The U87 and MG-63 cell lines were obtained from the Type Culture Collection of the Chinese Academy of Sciences. The cells were grown and maintained on the substrates (nanotubes and titanium) in Dulbecco's Modified Eagle's Medium (high glucose; Hyclone, Logan, UT, USA) supplemented with 10\% fetal bovine serum (Hyclone). The medium was changed every 2 days, and the cells were enzymatically passaged with $0.25 \%$ trypsin digestion. Cells at the logarithmic growth phase were cultured on the substrates at a density of $5 \times 10^{5} / \mathrm{mL}$ for an additional 24 hours in a standard tissue culture incubator at $37^{\circ} \mathrm{C}$ with $5 \% \mathrm{CO}_{2}$ and $100 \%$ relative humidity.

\section{Cell morphology by scanning electron microscopy}

After being cultured for 24 hours, the cells on the substrate were washed twice with phosphate-buffered saline to remove the nonadherent cells and fixed in $2.5 \%$ glutaraldehyde (Sigma-Aldrich, St Louis, MO, USA) for 2 hours at $4^{\circ} \mathrm{C}$. Next, the surfaces were subjected to two 10-minute washes with phosphate-buffered saline and post-fixed in $1 \%$ osmium tetroxide (Sigma-Aldrich) for one hour at $4^{\circ} \mathrm{C}$. Subsequently, each specimen was washed twice with phosphate-buffered saline for 10 minutes, dehydrated by increasing concentrations of ethanol $(35 \%, 50 \%, 75 \%, 90 \%$, and $100 \%)$ for 15 minutes, and then dried at room temperature. The dried specimens were sputter-coated with gold and observed under a scanning electron microscope (JSM-6500F, JEOL Ltd, Tokyo, Japan).

\section{Cell adhesion and proliferation assay}

For cell adhesion, $2 \times 10^{5}$ U87 cells were seeded on nanotubes or the titanium substrate in a 6 -well plate for 6 hours and 24 hours. The nonadherent cells were washed away, and the adherent cells in ten random fields were counted under a fluorescence microscope (40× magnification). Cell viability was examined by the 3-(4,5-dimethylthiazol-2-yl)-2,5-diphenyltetrazolium bromide (MTT) assay. After being cultured for 24 hours, the cells were digested from the specimens and maintained in $2 \mathrm{~mL}$ of Dulbecco's Modified Eagle's Medium. The MTT assay was performed according to the previous report, with minor modifications. ${ }^{31}$ Each sample $(200 \mu \mathrm{L})$ was seeded in a 96-well plate in five duplicates. MTT ( $20 \mu \mathrm{L}, 5 \mathrm{mg} / \mathrm{mL}$; Sigma-Aldrich) was added to each well, and the mixture was incubated at $37^{\circ} \mathrm{C}$ for an additional 4 hours. After aspirating the solution from each well, $150 \mu \mathrm{L}$ of dimethyl sulfoxide (Sigma-Aldrich) was added into each well to dissolve the crystals. After shaking for 10 minutes, the absorbance at $490 \mathrm{~nm}$ was detected with a microplate reader (Bio-Rad, Hercules, CA, USA). All experiments were repeated three times. Cell viability was determined by the following equation:

$$
\text { Cell viability }(\%)=\left(\mathrm{Abs}_{\text {test cells }} / \mathrm{Abs}_{\text {control cells }}\right) \times 100 \% \text {. }
$$

\section{Cell migration assay}

The cell migration assay was performed using a Transwell plate ( $8 \mu \mathrm{M}$ polycarbonate Med plate, $6.5 \mathrm{~mm}$ inserts, Costar, New York, NY, USA). A total of $1.0 \times 10^{5}$ U87 cells were cultured in a 6-well plate precoated with $\mathrm{TiO}_{2}$ nanotubes with different diameters for 24 hours and then detached from the plate by washing with phosphate-buffered saline. A total of $3.0 \times 10^{3}$ cells in $100 \mu \mathrm{L}$ of serum-free Dulbecco's Modified Eagle's Medium containing 0.1\% bovine serum albumin were added to the top of each migration chamber and allowed to migrate for 20 hours in the presence of $20 \%$ fetal calf serum in the lower chamber. The cells on the top chamber were wiped away by a wet cotton swap, and the cells that had migrated were fixed in $100 \%$ methanol and stained with Giemsa (Sigma-Aldrich). The migrated cells were visualized using bright-field microscopy (Nikon, Tokyo, Japan), and the number of cells in ten random fields (20× magnification) was counted.

\section{Immunofluorescence microscopy}

U87 and MG-63 cells were adjusted to a density of $1.0 \times$ $10^{4}$ cells $/ \mathrm{cm}^{2}$ and seeded on the nanotube coatings with or without annealing. After 24 hours, the cells were washed with phosphate-buffered saline and fixed with $4 \%$ paraformaldehyde for 20 minutes. The cells were blocked with horse serum (1:20 dilution, Jackson ImmunoResearch, West Grove, PA, USA) for one hour at room temperature, immunolabeled with the primary antibodies anti-rabbit caspase-3 (1:100 dilution, Bioss Inc, Woburn, MA, USA) and anti-mouse acetylated $\alpha$-tubulin (1:150 dilution, Abcam, Cambridge, MA, USA) overnight at $4^{\circ} \mathrm{C}$, washed with phosphate-buffered saline three times, and immunolabeled with the appropriate secondary antibodies (fluorescein isothiocyanate conjugation for acetylated $\alpha$-tubulin and tetramethylrhodamine-5-(and 6)-isothiocyanate conjugation for caspase-3, 1:50 dilution, Jackson ImmunoResearch) for one hour in the dark. The cells were washed in phosphate-buffered saline. The coverslips were mounted on slides with ProLong ${ }^{\circledR}$ Gold Antifade Mountant and 4,6-diamidino-2-phenylindole (DAPI; Invitrogen, Life Technologies, Carlsbad, CA, USA) before 
storage at $4^{\circ} \mathrm{C}$. The cells were imaged using a Leica confocal microscope (Leica, Wetzlar, Germany). Fluorescence signals were captured after excitation with 355,488 , and $543 \mathrm{~nm}$ laser lines.

\section{Western blot assay}

Several proteins were quantified using a Western blot assay, including phosphor-focal adhesion kinase (p-FAK), vitronectin, Bax, Bcl-2, and caspase-3, with glyceraldehyde-3phosphate dehydrogenase used as a loading control. In brief, the U87 cells were cultured on the surface of nanotubes with different nanotopographic characteristics and smooth titanium, respectively, in Dulbecco's Modified Eagle's Medium containing $10 \%$ fetal bovine serum. After being cultured for 24 hours, the cells were collected, washed, centrifuged, and lysed at $4{ }^{\circ} \mathrm{C}$. The protein concentration was quantified using a bicinchoninic acid protein assay kit (R\&D Systems, Minneapolis, MN, USA), according to the manufacturer's instructions. Sodium dodecyl sulfate-polyacrylamide gel electrophoresis and Western blot analysis were then performed as described previously, with minor modifications. ${ }^{32}$ A total of $50 \mu \mathrm{g}$ of protein from each sample was resolved by sodium dodecyl sulfate polyacrylamide gel electrophoresis, transferred onto polyvinylidene fluoride membranes (Roche, Indianapolis, IN, USA) by electroblotting, and probed with specific primary antibodies, including monoclonal mouse anti-p-FAK (1:1,000, Santa Cruz Biotechnology, Santa Cruz, CA, USA), monoclonal mouse anti-human vitronectin (1:1,000, R\&D Systems), monoclonal mouse anti-human Bcl-2 (1:500, Santa Cruz Biotechnology), monoclonal mouse anti-human Bax (1:500, Santa Cruz Biotechnology, and monoclonal mouse anti-human caspase-3 (1:1,000, R\&D Systems). The primary antibodies were detected using horseradish peroxidase-conjugated goat anti-mouse IgG (1:5,000, Promega, Heidelberg, Germany) in blocking solution. Immunoreactive protein bands were detected with an enhanced chemiluminescence reagent (ECL-Plus, Amersham Pharmacia Biotech, Piscataway, NJ, USA) and densitometrically quantitated according to the manufacturer's instructions.

\section{Statistical analysis}

All experiments were repeated three times, and all quantitative data were presented as the mean \pm standard deviation. Statistical comparisons were made with the Student's $t$-test. The significance was determined by one-way analysis of variance using Statistical Package for the Social Sciences version 10.0 software (SPSS Inc, Chicago, IL, USA).

\section{Results and discussion \\ Effect of nanotube diameter on morphology and spreading of cells}

Figure 1 shows the $\mathrm{TiO}_{2}$ nanotube array coating fabricated under different voltages $(20-60 \mathrm{~V})$. The diameter of the nanotubes varied from $20 \mathrm{~nm}$ to $120 \mathrm{~nm}$. When the U87 cells were cultured on the nanotube coatings with different diameters in Dulbecco's Modified Eagle's Medium containing $10 \%$ fetal bovine serum for 24 hours, the cells exhibited gradual changes in the morphology and spreading tendency on nanotubes with different diameters (Figure 2). The cells became fusiform-shaped in a single direction on the surface of smooth titanium. On the surface of the $20 \mathrm{~nm}$ nanotube

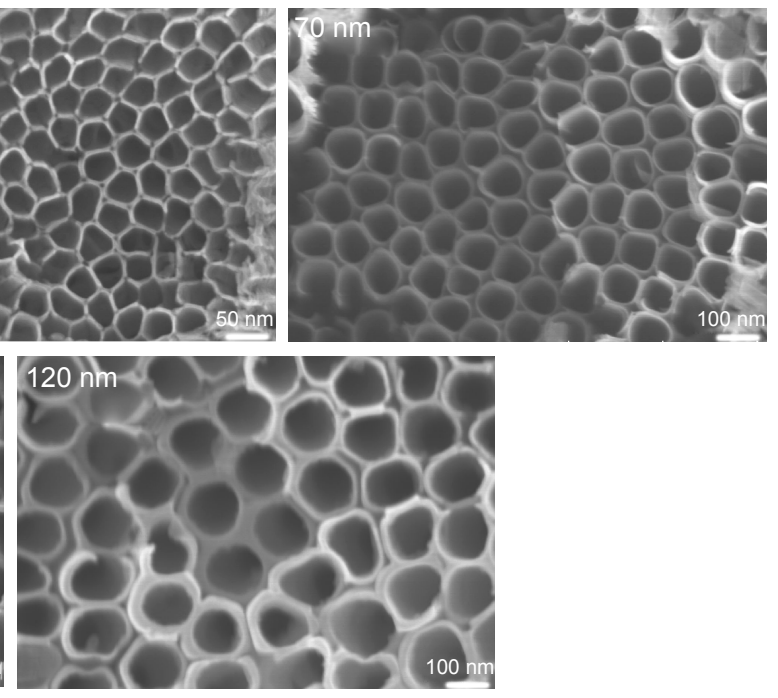

Figure I Sectional layer of vertically oriented $\mathrm{TiO}_{2}$ nanotubes with different diameters. 

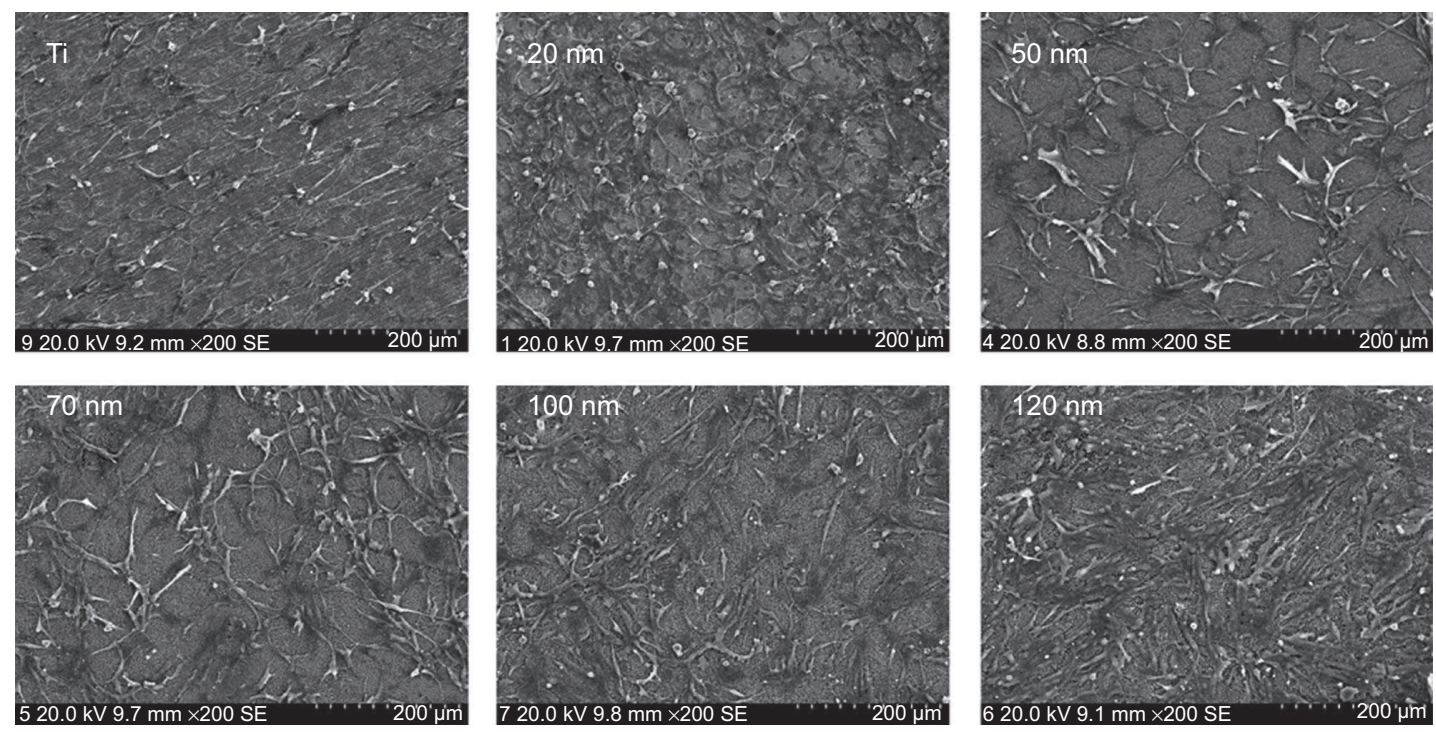

Figure 2 Scanning electron microscopic images of U87 cells cultured on amorphous nanotube coatings. Abbreviation: $\mathrm{Ti}$, titanium.

coating, the U87 cells attached tightly to the coating. The fiber-like extensions of the cells spread in many directions and formed a complex network on the coating. On the surface of the 50-70 nm nanotube coatings, the cell density was significantly reduced $(P<0.05)$ and the cell morphology became more elongated; however, the network pattern was still present. On the surface of the 100-120 nm nanotube coatings, the cell density was similar to that on the 50-70 $\mathrm{nm}$ coatings, but the cells became flat and were connected in a cluster pattern.

Cells usually spread on a substrate surface via lamellipodia and filopodia. Filopodia often serve as the "sensor" to detect the morphology of the substrate surface and as an effective apparatus of the inducible factor of neurites via the recruiting microfilament to determine the growth direction of growing neurites. Correspondingly, the lamellipodia are related to rapid cell movement. ${ }^{33}$ Detailed images depicting the morphology of cells on the surface of different samples are shown in Figure 3. Cells on the $20 \mathrm{~nm}$ nanotube coating stretched out numerous pseudopodia in multiple directions and exhibited a radial appearance. Meanwhile, tiny filiform pseudopodia were presented as big sheets of pseudopodia (Figure 3A and 3B). Although there were some microfilaments and pseudopodia stretched on the surface of the smooth titanium (Figure 3E and $3 \mathrm{~F}$ ) and the $120 \mathrm{~nm}$ nanotube coating, it was obviously less than that on the $20 \mathrm{~nm}$ nanotube coating. In addition, cells on the $120 \mathrm{~nm}$ nanotube coating appeared broken (Figure 3C), and their pseudopodia showed a tendency to escape and stretch to the tube walls at the connection of the nanotubes (Figure 3D). Moreover, we observed that the expression of p-FAK and vitronectin in the U87 cells cultured on the $20 \mathrm{~nm}$ nanotube coatings was obviously increased, while their expression was significantly decreased in the U87 cells cultured on the $120 \mathrm{~nm}$ nanotube coatings ( $P<0.05$, Figure $4 \mathrm{~A}$ and $4 \mathrm{~B})$.

Both the tube walls and tube holes on the nanotubes can affect cell morphology, thereby stimulating a series of cellular behaviors, such as cell adhesion, migration, and expansion. However, based on our results, compared with the surface of smooth titanium, not all cells cultured on the nanotube coatings showed obvious migration and attachment. This result suggests that the geometrical characteristics of the nanotubes affect the biological behavior of U87 cells. Cell adhesion and morphology are related to integrin receptors. Compared with some surface proteins, integrins are influenced by the topography of the cell adhesion interface. ${ }^{34}$ The biological behaviors of connective tissue cells on the nanotube coating indicate that nanotubes with a diameter of $15-30 \mathrm{~nm}$ can be used as ideal materials to promote integrin assembly into focal adhesion complexes. ${ }^{24}$ However, when the diameter is larger than a certain threshold, ${ }^{35}$ the nanotubes will no longer support the integrin assembly. Therefore, cell migration and spreading are subject to certain constraints. In this study, the changes in cell morphology on different surfaces suggest that the growth of U87 cells on different nanotube coatings was size-dependent. We observed not only lamellipodia extension in various directions but also typical fan-shaped, fast-moving cells on the $20 \mathrm{~nm}$ nanotube coating, indicating that the cells embody free migration trends, while on the $100-120 \mathrm{~nm}$ nanotube coatings, the migration, adsorption, 

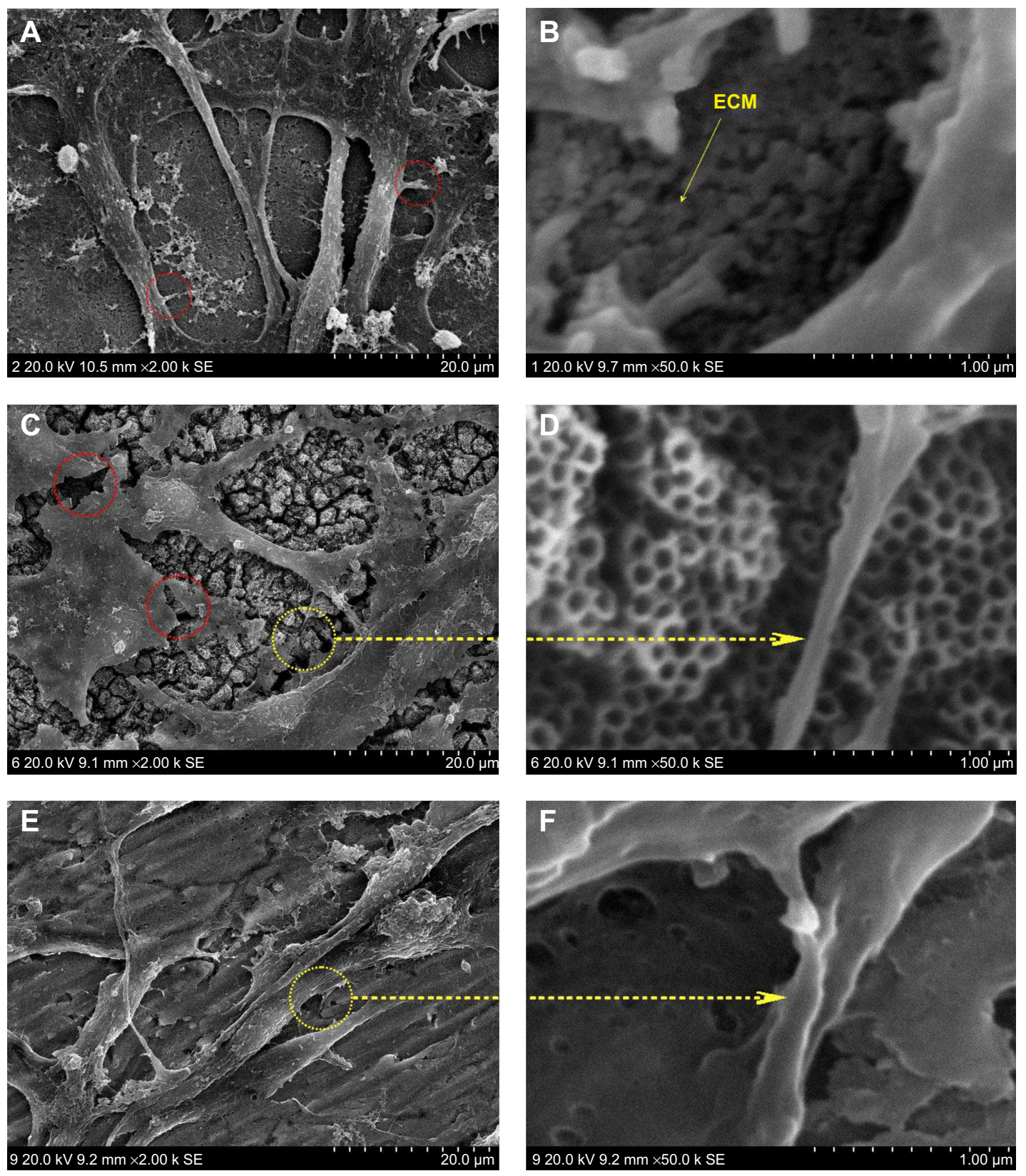

Figure 3 High magnification scanning electron microscopic images of U87 cells.

Notes: (A) U87 cells cultured on $20 \mathrm{~nm}$ nanotubes. The red circles indicate the tiny filiform pseudopodia. (B) The ECM component is deposited on the $20 \mathrm{~nm}$ nanotubes. (C) U87 cells cultured on $120 \mathrm{~nm}$ nanotubes. The red circles indicate the fracture of the cells. (D) Cell extensions protrude to the tube walls. (E) U87 cells cultured on smooth titanium substrate. (F) Microfilaments and pseudopodia stretched on the surface of smooth titanium.

Abbreviation: ECM, extracellular matrix.

and spread of cells were obviously suppressed. However, a large number of cell clusters implied that the cell behaviors on the nanotube coating surface are also affected by other factors besides integrins. The extracellular matrix (ECM) consists mainly of collagen, polysaccharides, and proteoglycans, which perform many functions, such as biological signal transmission, regulating cell adhesion and migration. ${ }^{36}$ The composition, density, and distribution characteristics of the ECM on the surface can affect cell biological behavior. ${ }^{37}$ Cell adhesion to the ECM mostly leads to clustering of integrins into focal adhesion complexes and recruitment of functional proteins, including fibronectin, FAK, extracellular-regulated kinase, and others. In this study, we analyzed the expression of p-FAK and vitronectin. FAK has been found to serve as an executor to connect cadherin to actin in the cytoskeleton ${ }^{38}$ and to influence cellular behaviors, including spreading, migration, and adhesion. ${ }^{4}$ Vitronectin can markedly promote glioma activation ${ }^{39}$ and is responsible for protection against apoptosis. ${ }^{40}$ In particular, vitronectin is an important component of the ECM and serves as a biomarker for cell adhesion 
A

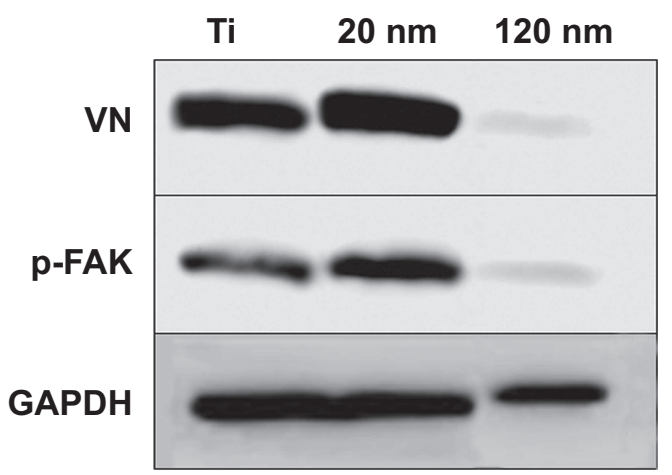

B

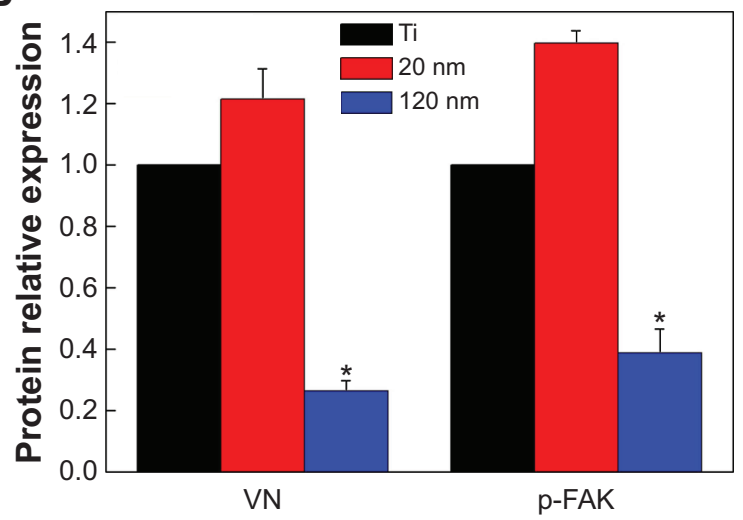

Figure 4 Expression of vitronectin and P-FAK in U87 glioma cells cultured on nanotubes with different diameters.

Notes: (A) Western blot analysis of the expression of vitronectin and p-FAK. (B) Statistical analysis of vitronectin and P-FAK expression. The densities of the vitronectin and p-FAK bands were measured, and the ratio was calculated. $* P<0.05$ compared with titanium and $20 \mathrm{~nm}$ nanotubes.

Abbreviations: p-FAK, phosphor-focal adhesion kinase; VN, vitronectin; GAPDH, glyceraldehyde-3-phosphate dehydrogenase; $\mathrm{Ti}$, titanium.

and spreading. Cell adhesion to the ECM facilitates the binding of integrins to functional proteins such as vitronectin and fibronectin. Vitronectin can bind with integrins and possesses competitive advantages compared with other major proteins. For instance, the adhesion of smooth muscle cells to substrates is controlled by fibronectin and vitronectin in the initial 24 hours, but cells preferentially bind to vitronectin after 24 hours ${ }^{41}$ Here, we observed that the expression levels of vitronectin and p-FAK in U87 cells cultured on nanotubes with different diameters were size-dependent; they increased on the $20 \mathrm{~nm}$ nanotube coating but decreased on the $120 \mathrm{~nm}$ nanotube coating (Figure 4). In addition, the lack of FAK results in increased cell-cell adhesion but reduced cell-matrix contacts. ${ }^{4}$ Therefore, on the nonadhesive surface, the naked nanotubes without the ECM coating failed to form a natural membrane (Figure 3D) for cell embedding (as Figure 3B shows) and could not coordinate with the integrins to form adhesion plaques. Instead, they promoted cell-cell contacts to replace the cell-matrix contacts.
Our results indicate that the behavior of U87 cells on the nanotube coatings is regulated in a coordinated manner by direct effects of the cell-material interaction and indirect effects of the protein-material-cell interactions. The direct effects include integrin receptors responding to the changes in diameters and transmission of the topography cues to the nucleus to control cell behaviors, while the indirect effects include transmission of outside signals by the ECM to the nucleus via integrins.

\section{Effects of crystalline structure on cell morphology and spreading}

To further evaluate the effects of the crystal structure of the $\mathrm{TiO}_{2}$ nanotube coatings on $\mathrm{U} 87$ cell behaviors, we examined the morphology of the U87 cells on the nanotubes after annealing. As shown in Figure 5A and 5B, the morphology of the cells on the nanotube coatings was almost the same as that on the amorphous nanotubes (Figure 2). After annealing, the nanotube coating became a mixed crystal structure of rutile and anatase (Figure 5C). Compared with the amorphous coating, the wetting angle of the coating with the mixed crystal structure was lower (Figure 5D). ${ }^{42}$ However, the morphology and spreading behavior of the U87 cells did not appear to be affected by changes in the crystalline structure or the hydrophilic properties of the coatings after being cultured for 24 hours. Moreover, the expression of p-FAK and vitronectin in U87 cells was not obviously affected by the phase of the nanotubes, but the expression of p-FAK and vitronectin in the U87 cells cultured on the $120 \mathrm{~nm}$ nanotube coating was significantly decreased compared with that on the $20 \mathrm{~nm}$ nanotube coating, regardless of whether annealing occurred $(P<0.05$, Figure 5E and 5F). These results indicate that the cell morphology may be controlled mainly by the nanotube coating surface topography. If the annealing temperature does not change the morphology of the coating, the morphological differences of cells on the $\mathrm{TiO}_{2}$ with different crystal structures are not obvious. ${ }^{43}$ On the contrary, if a higher annealing temperature damages the coating morphology, subsequent expression of adhesion proteins will also be changed, and cell morphology and spreading will be affected. ${ }^{43}$ The morphology and spreading of U87 cells on the nanotube coating rely mainly on integrins and adhesion proteins, both of which seem not to respond sensitively to changes in the coating crystalline structure.

\section{Role of phase and topography of $\mathrm{TiO}_{2}$ nanotubes in supporting cell activities}

The MTT assay was performed to evaluate the effect of the topography and crystal structure of the nanotube coatings 
A

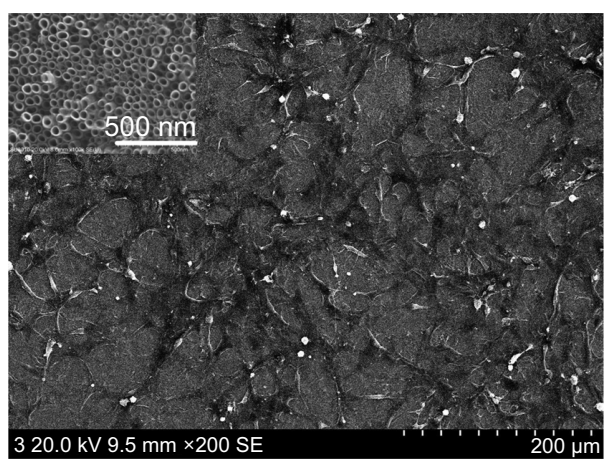

C



$\mathbf{E}$



B
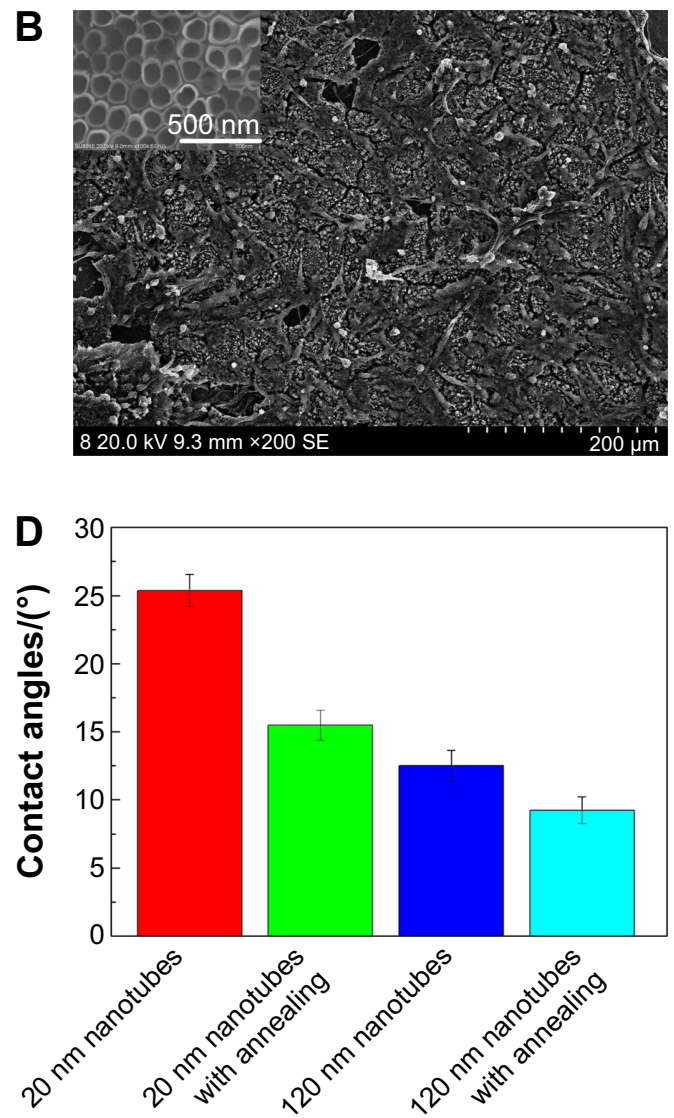

$\mathbf{F}$

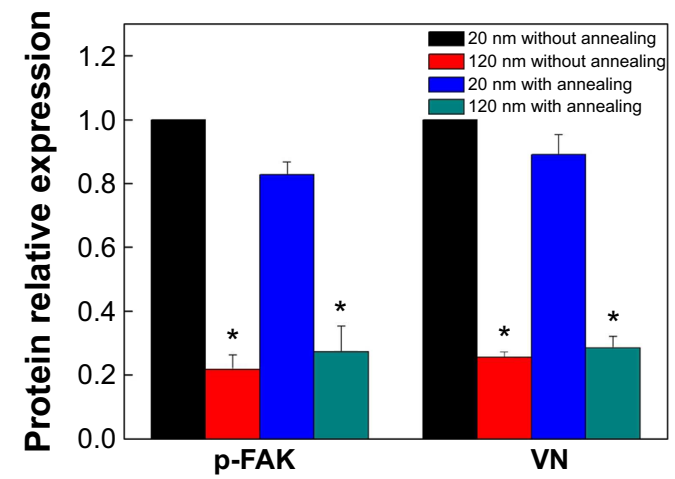

Figure 5 Cell morphology, crystallinity, and contact angle of the $\mathrm{TiO}_{2}$ nanotubes.

Notes: (A) Scanning electron micrographs of U87 glioma cells on the $20 \mathrm{~nm}$ nanotubes with annealing at $450^{\circ} \mathrm{C}$. (B) Scanning electron micrographs of U87 cells on the I20 nm nanotubes with annealing at $450^{\circ} \mathrm{C}$. (C) X-ray diffraction patterns for amorphous nanotubes and annealed nanotubes. (D) Contact angles of amorphous nanotubes and annealed nanotubes. (E) Expression levels of vitronectin and p-FAK in U87 glioma cells cultured on $20 \mathrm{~nm}$ and I20 nm nanotubes with or without annealing. (F) Statistical analysis of vitronectin and $\mathrm{p}$-FAK expression. The densities of vitronectin and $\mathrm{p}$-FAK bands were measured, and the ratio was calculated. $* \mathrm{P}<0.05$, compared with the $20 \mathrm{~nm}$ nanotubes. Abbreviations: au, absorbance units; p-FAK, phosphor-focal adhesion kinase; VN, vitronectin; GAPDH, glyceraldehyde-3-phosphate dehydrogenase; Ti, titanium.

on the viability of U87 and MG-63 cells (Figure 6). The cell viability of U87 cells plated on the $20 \mathrm{~nm}$ nanotube coating was significantly higher than that on the other sized coatings $(P<0.05)$. When the nanotube diameter was larger than $50 \mathrm{~nm}$, the cell viability decreased. Moreover, the annealed nanotube coatings did not significantly promote cell viability $(P>0.05)$, compared with the same diameter of amorphous nanotubes (Figure 6A). Similar results were observed for MG-63 cells, in which cell viability was significantly elevated $(P<0.05)$ on the $20 \mathrm{~nm}$ nanotube coating with or without annealing but was obviously decreased on the $120 \mathrm{~nm}$ nanotube coating (Figure $6 \mathrm{~B})$. We further examined the effect of different diameters of $\mathrm{TiO}_{2}$ coating on adhesion of $\mathrm{U} 87$ cells. After cell culture 
A

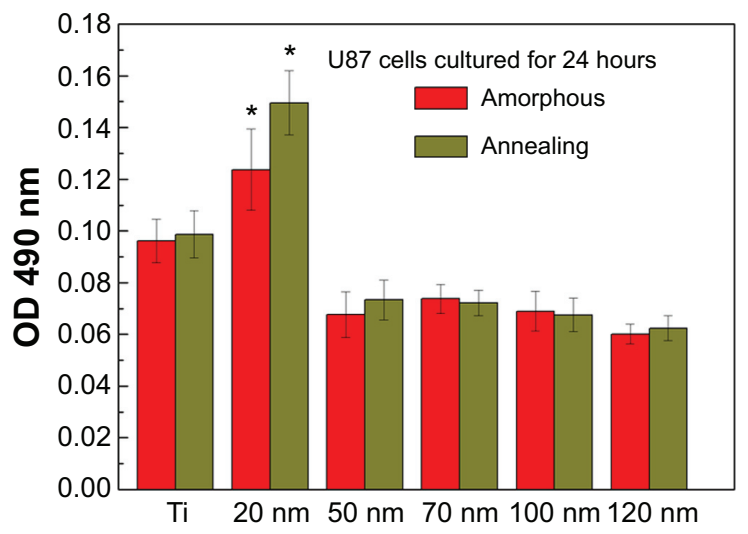

B

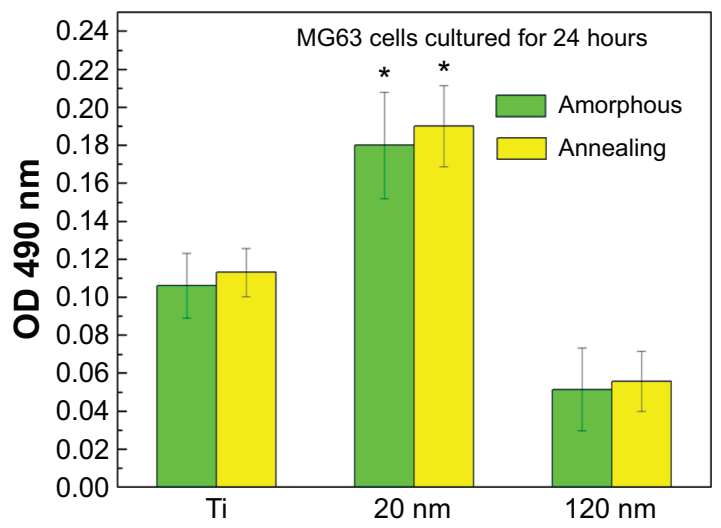

Figure 6 Viability of U87 (A) and MG-63 (B) cells on nanotubes with different diameters after cell culture for 24 hours. The data are presented as the mean \pm standard deviation $(\mathrm{n}=3)$. $* P<0.05$ versus titanium, $50 \mathrm{~nm}, 70 \mathrm{~nm}, 100 \mathrm{~nm}$, and $120 \mathrm{~nm}$ samples.

Abbreviations: $\mathrm{Ti}$, titanium; $\mathrm{OD}$, optical density.

for 24 hours, the cell numbers on the $20 \mathrm{~nm}$ nanotube coating with or without annealing were significantly greater than those on the larger diameter nanotube coatings (Figure 7A, $P<0.05)$. Meanwhile, we examined the migratory capacity of $U 87$ cells on the nanocoatings. The migratory capacity of the U87 cells was significantly improved when they were cultured on the $20 \mathrm{~nm}$ nanotube coating with or without annealing, while the migratory capacity of the U87 cells on the $120 \mathrm{~nm}$ nanotube coating was dramatically reduced compared with the titanium coating (Figure $7 \mathrm{~B}$ and $7 \mathrm{C}$, $P<0.05$, the images of the Transwell assay as well as the nuclear staining of U87 cells are included in the Supplementary materials section; Figure S1, S2, S3 and S4). It has been demonstrated that microtubules consisting of $\alpha$-tubulin and $\beta$-tubulin heterodimers are involved in cell movement, intracellular trafficking, and mitosis. ${ }^{44}$ Acetylated $\alpha$-tubulin is a component of long-lived and stable microtubules, and deacetylation of $\alpha$-tubulin enhances cell motility. ${ }^{44}$ Compared with the titanium coating, the expression of acetylated $\alpha$-tubulin in U87 and MG-63 cells cultured on the $20 \mathrm{~nm}$ nanotube coating was obviously lower with or without annealing, while its expression was increased in cells cultured on the $120 \mathrm{~nm}$ nanotube coating (Figures 7D, 7E, and 9).

These data are consistent with the changes in migratory capacity of cells cultured on nanotube coating with different diameters. The basic unit of the connecting structure between cells and nanotubes is the ECM-integrin-cytoskeleton, and downregulation of p-FAK and vitronectin in cells cultured on nanotubes with larger diameters implies that the lack of functional ECM production may impair cell adhesion to the ECM, which inhibits the binding of integrins to the focal adhesion complex and activation of intracellular signal transmission into the cytoskeleton. ${ }^{24}$

Based on our findings, we predict that a diameter in the range of $15-30 \mathrm{~nm}$ is the most suitable for integrin assembly into focal contacts ${ }^{45}$ to further enhance cell migration, differentiation, and proliferation. ${ }^{24}$ In addition, although coatings with a mixed crystallinity structure have high surface energy, ${ }^{42}$ the influence of changes in the crystalline structure on ECM-integrin-cytoskeleton formation is relatively minor compared with the nanotopography. Thus, coatings with mixed crystal phases cannot obviously promote cell proliferation. We can infer that a nanotube diameter of 15-30 nm may represent a constant threshold to support major cellular responses to the nanotube surface in certain tumor cells. However, it should be noted that certain other factors, such as the crystallinity, residual fluorine, ${ }^{43}$ nanotube length, cell seeding density, and incubation time, ${ }^{20}$ may more or less affect the biological behaviors of cells on the nanotubes, although these factors need to be verified in a future study.

\section{Effects of phase and topography of $\mathrm{TiO}_{2}$ nanotubes on cell apoptosis}

To further investigate the consequences of reduced cell motility and proliferation on nanotubes with a large diameter, we sought to examine the expression of several apoptosis-related proteins by Western blot. Bcl-2 is a potent suppressor of cell apoptosis ${ }^{46}$ while Bax is a proapoptotic member of the Bcl-2 protein family; overexpression of Bax indicates an apoptosis-inducing tendency. ${ }^{47}$ Regardless of whether an extrinsic or intrinsic apoptotic pathway is activated, caspase- 3 is always activated downstream of apoptotic pathways ${ }^{48}$ and plays an important role in cell death. 

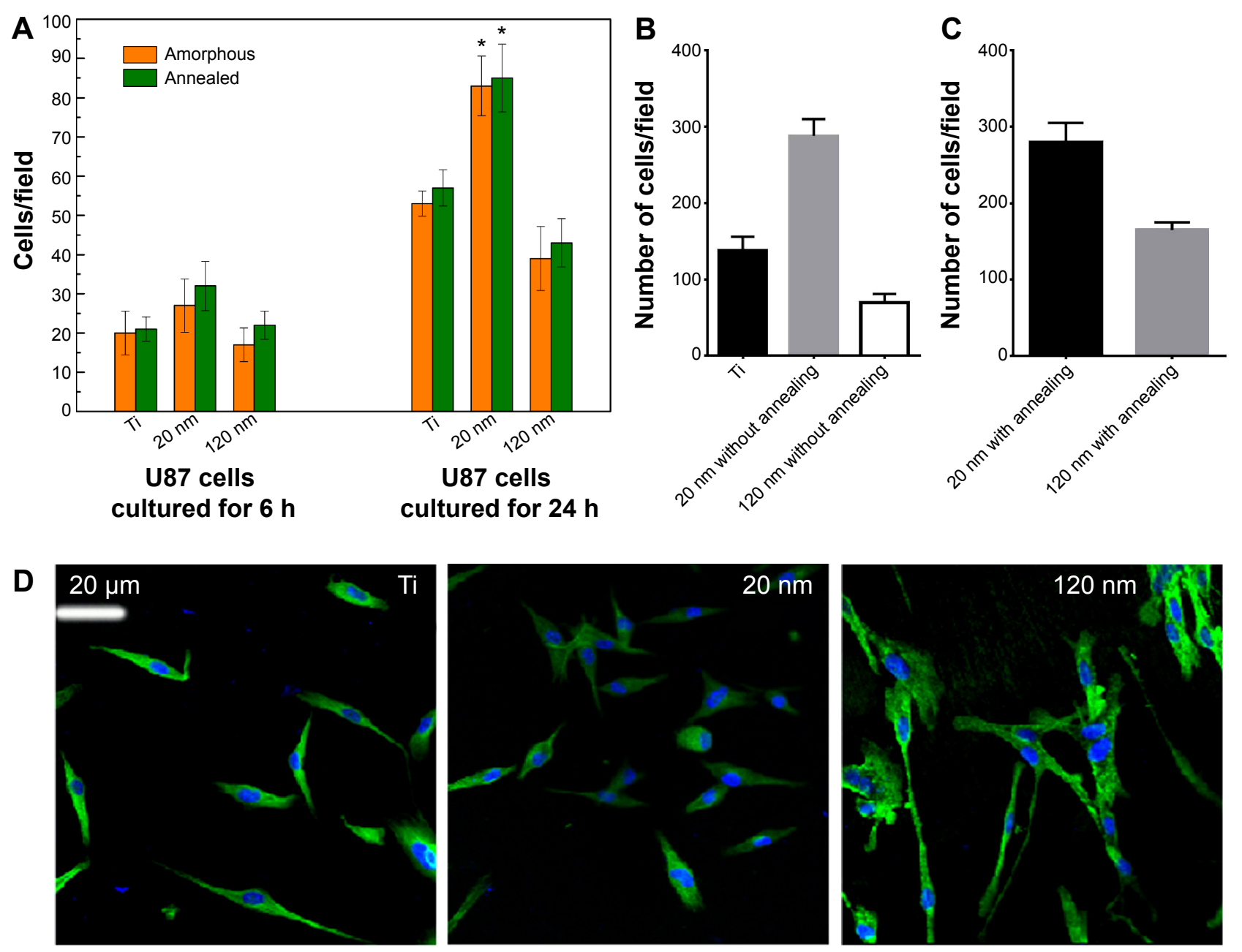

$\mathbf{E}$


Figure 7 (A) Adhesion of U87 cells to titanium and $20 \mathrm{~nm}$ and $\mathrm{I} 20 \mathrm{~nm}$ nanotubes. $* \mathrm{P}<0.05$ compared with titanium and I $20 \mathrm{~nm}$ nanotubes. (B, C) Migratory capacity of U87 cells on nanotubes with different diameters without $(\mathbf{B})$ and with $(\mathbf{C})$ annealing. (D, E) Immunofluorescence of acetylated $\alpha$-tubulin expression in U87 cells cultured on nanotubes with different diameters without $(\mathbf{D})$ and with $(\mathbf{E})$ annealing.

Abbreviation: $\mathrm{Ti}$, titanium.

Here, we observed that the expression levels of $\mathrm{Bax}, \mathrm{Bcl}-2, \quad \mathrm{Bax}$ is also an important parameter. It was found that the and caspase- 3 were changed. As shown in Figure 8A and 8B, the level of Bcl-2 protein was increased but the expression of Bax and caspase-3 proteins was reduced in U87 cells cultured on the $20 \mathrm{~nm}$ nanotube coatings. The ratio of Bcl-2/ Bcl-2/Bax ratio was highest in cells cultured on the $20 \mathrm{~nm}$ nanotube coating. Moreover, the double immunostaining of caspase- 3 and acetylated $\alpha$-tubulin revealed obviously higher caspase-3 and acetylated $\alpha$-tubulin expression levels 
A

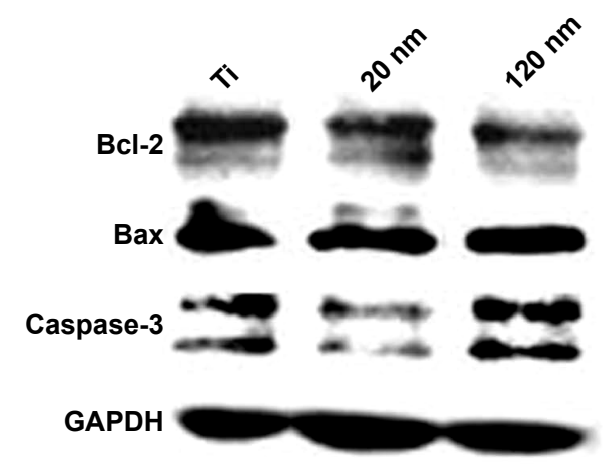

B

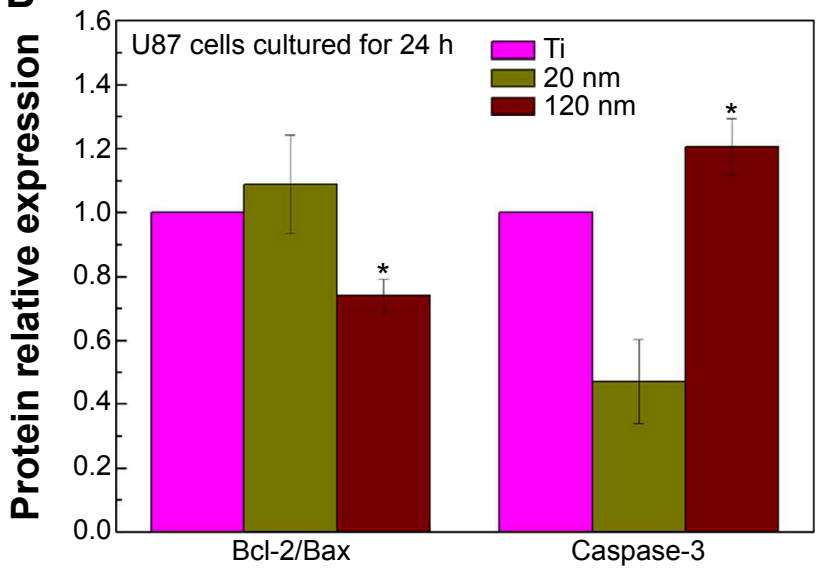

C
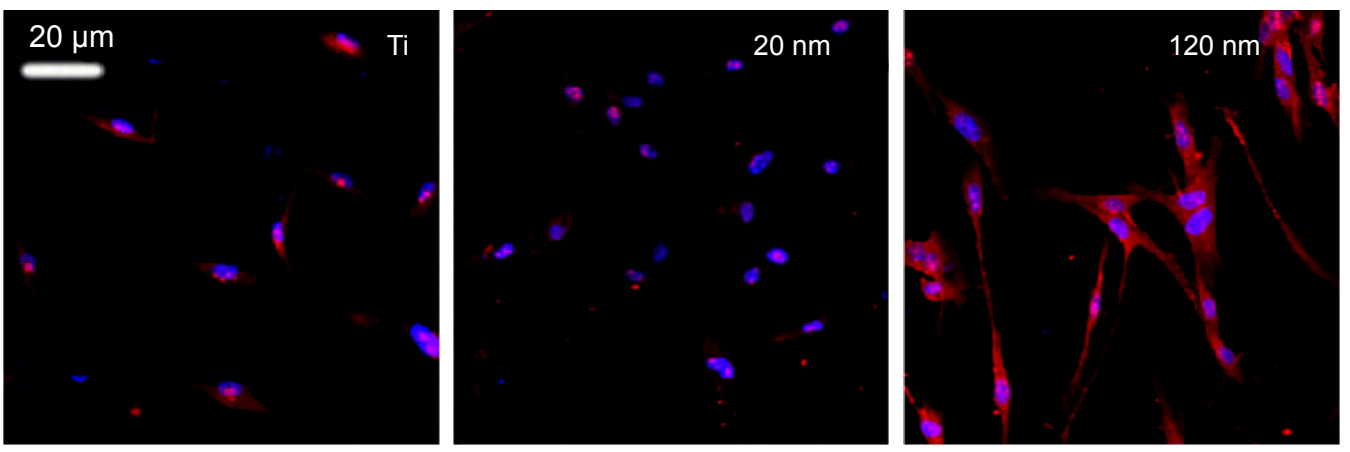

D
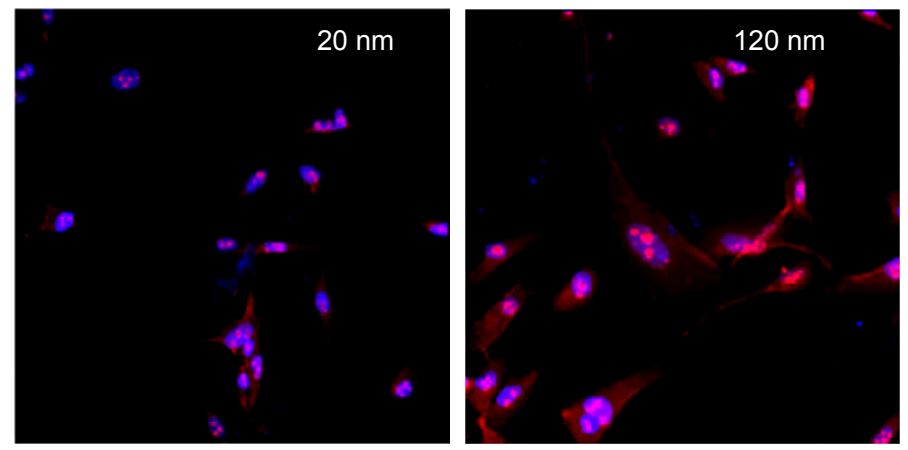

Figure 8 Effect of nanotubes with different diameters on the apoptosis of U87 cells.

Notes: (A) Expression of Bcl-2, Bax, and caspase-3 in U87 cells cultured on nanotubes with different diameters without annealing. (B) Statistical analysis of Bcl-2, Bax, and caspase-3 expression. ${ }^{*} P<0.05$, compared with the $20 \mathrm{~nm}$ nanotubes. (C, D) Immunostaining of caspase-3 in U87 cells cultured on nanotubes with different diameters without (C) and with (D) annealing.

Abbreviations: GAPDH, glyceraldehyde-3-phosphate dehydrogenase; Ti, titanium.

in U87 and MG-63 cells cultured on the $120 \mathrm{~nm}$ nanotube coating, but significantly lower caspase-3 and acetylated $\alpha$-tubulin expression levels in the same cells cultured on the $20 \mathrm{~nm}$ nanotube coating (Figures 7D, 7E, 8C, 8D, 9A, and $9 \mathrm{~B}$, the immunostaining images including the nuclear staining of U87 cells and MG63 cells were provided in Supplementary materials; Figures S5, S6, S7 and S8). These data are consistent with the robust cell viability and proliferation results on the $20 \mathrm{~nm}$ nanotube coating. Similar findings for the different cell types indicate that the effects of nanotube diameter on cell activity are not cell type-specific.
In glioma, induction of apoptosis is especially of importance in the investigation of effective therapies. Thus, considering the caspase- 3 Western blot and immunostaining data, the 20 $\mathrm{nm}$ nanotubes seemed to promote proliferation of U87 cells and MG-63 cells, although further investigation is needed to explore the underlying mechanisms.

\section{Conclusion}

Our data demonstrate that the effects of nanotube diameter on the behavior of glioblastoma and osteosarcoma cells are size-dependent. The critical threshold diameter for the 
A
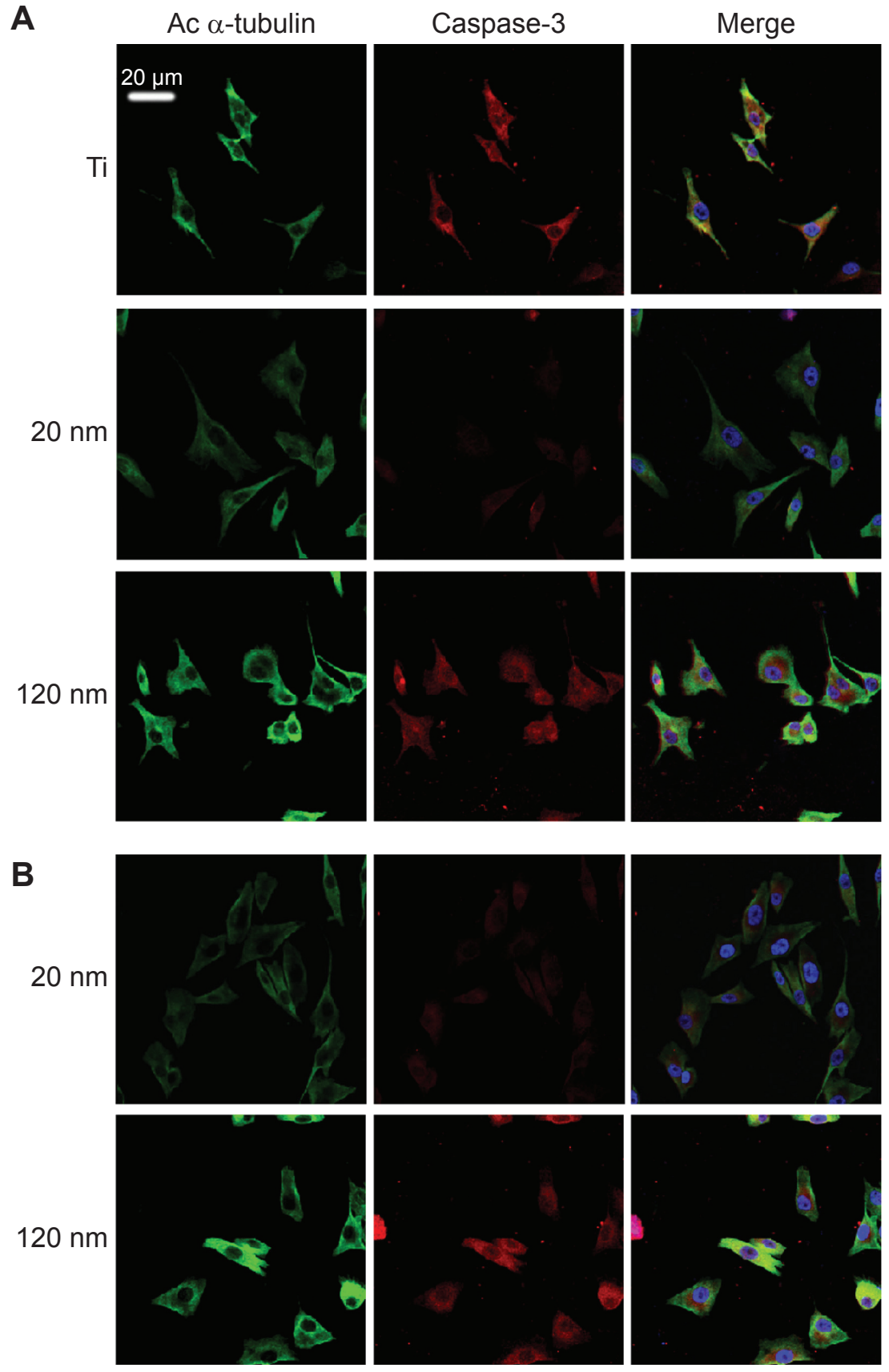

Figure 9 Double staining of caspase-3 and acetylated $\alpha$-tubulin expression in MG-63 cells cultured on nanotubes with different diameters without (A) and with (B) annealing. Abbreviations: Ac, acetylated; Ti, titanium.

nanotubes is $20 \mathrm{~nm}$ for adhesion, spreading, and proliferation of cells. Larger nanotube diameters result in reduced cell migration capacity and proliferation as well as increased cell apoptosis. Thus, the size of the nanotube system regulates cell behavior, and this information will be useful for future biomedical and clinical applications.

\section{Acknowledgment}

Support for this work by the National Natural Science Foundation of China (50872019, 51002027), Post Doctoral
Foundation of China (2013M530930), Foundation from Liaoning Province Department of Education Research Project (L2012084), Basic Scientific Research Foundation of Central College (N130402001), Liaoning Provincial Natural Science Foundation of China (2013021075 to Bo Qiu) and the Fund for Scientific Research of the First Hospital of China Medical University (fsfh1304 to Bo Qiu) is gratefully acknowledged.

\section{Disclosure}

The authors report no conflicts of interest in this work. 


\section{References}

1. Khang D, Choi J, Im YM, et al. Role of subnano-, nano- and submicronsurface features on osteoblast differentiation of bone marrow mesenchymal stem cells. Biomaterials. 2012;33:5997-6007.

2. Guiseppi-Elie A, Dong C, Dinu CZ. Crosslink density of a biomimetic poly(HEMA)-based hydrogel influences growth and proliferation of attachment dependent RMS 13 cells. J Mater Chem. 2012;22:15929-15939.

3. Kotanen CN, Wilson AN, Dong CB, Dinu CZ, Justin GA, GuiseppiElie A. The effect of the physicochemical properties of bioactive electroconductive hydrogels on the growth and proliferation of attachment dependent cells. Biomaterials. 2013;34:6318-6327.

4. Lange J, Auernheimer V, Strissel PL, Goldmann WH. Influence of focal adhesion kinase on the mechanical behavior of cell populations. Biochem Biophys Res Commun. 2013;436:246-251.

5. Park J, Bauer S, Von Der Mark K, Schmuki P. Nanosize and vitality: $\mathrm{TiO}_{2}$ nanotube diameter directs cell fate. Nano Lett. 2007;7:1686-1691.

6. Park J, Bauer S, Pittrof A, Killian MS, Schmuki P, von der Mark K. Synergistic control of mesenchymal stem cell differentiation by nanoscale surface geometry and immobilized growth factors on $\mathrm{TiO}_{2}$ nanotubes. Small. 2012;8:98-107.

7. Polonchuk L, Elbel J, Eckert L, Blum J, Wintermantel E, Eppenberger HM. Titanium dioxide ceramics control the differentiated phenotype of cardiac muscle cells in culture. Biomaterials. 2000;21:539-550.

8. Pelipenko J, Kocbek P, Govedarica B, Rošic R, Baumgartner S, Kristl J. The topography of electrospun nanofibers and its impact on the growth and mobility of keratinocytes. Eur J Pharm Biopharm. 2013;84: 401-411.

9. Thomsen P, Malmström J, Emanuelsson L, René M, Snis A. Electron beam-melted, free-form-fabricated titanium alloy implants: material surface characterization and early bone response in rabbits. J Biomed Mater Res Part B. 2009;90B:35-44.

10. Lai YX, Xie C, Zhang Z, Lu W, Ding J. Design and synthesis of a potent peptide containing both specific and non-specific cell-adhesion motifs. Biomaterials. 2010;31:4809-4817.

11. Bet MR, Goissisa G, Vargas S, Selistre-de-Araujo HS. Cell adhesion and cytotoxicity studies over polyanionic collagen surfaces with variable negative charge and wettability. Biomaterials. 2003;24:131-137.

12. McNamara LE, Burchmore R, Riehle MO, et al. The role of microtopography in cellular mechanotransduction. Biomaterials. 2012;33: 2835-2847.

13. Chen CS, Mrksich M, Huang S, Whitesides GM, Ingber DE. Geometric control of cell life and death. Science. 1997;276:1425-1428.

14. Schwarz US, Bischofs IB. Physical determinants of cell organization in soft media. Med Eng Phys. 2005;27:763-772.

15. Pan Z, Yan C, Peng R, Zhao Y, He Y, Ding J. Control of cell nucleus shapes via micropillar patterns. Biomaterials. 2012;33:1730-1735.

16. Wu Y, Zitelli JP, TenHuisen KS, Yu X, Libera MR. Differential response of Staphylococci and osteoblasts to varying titanium surface roughness. Biomaterials. 2011;32:951-960.

17. Théry M, Racine V, Piel M, et al. Anisotropy of cell adhesive microenvironment governs cell internal organization and orientation of polarity. Proc Natl Acad Sci U S A. 2006;103:19771-19776.

18. Yang Y, Lai YK, Zhang QQ, et al. A novel electrochemical strategy for improving blood compatibility of titanium-based biomaterials. Colloids Surf B Biointerfaces. 2010;79:309-313.

19. Brammer KS, Oh S, Gallagher JO, Jin S. Enhanced cellular mobility guided by $\mathrm{TiO}_{2}$ nanotube surfaces. Nano Lett. 2008;8:786-793.

20. Yu WQ, Jiang XQ, Zhang FQ, Xu L. The effect of anatase $\mathrm{TiO}_{2}$ nanotube layers on MC3T3-E1 preosteoblast adhesion, proliferation, and differentiation. J Biomed Mater Res Part A. 2010;94A:1012-1022.

21. Park J, Bauer S, Schmuki P, von der Mark K. Narrow window in nanoscale dependent activation of endothelial cell growth and differentiation on $\mathrm{TiO}_{2}$ nanotube surfaces. Nano Lett. 2009;9:3157-3164.

22. Liao JJ, Lin SW, Yang Y, et al. Highly selective and sensitive glucose sensors based on organic electrochemical transistors using $\mathrm{TiO}_{2}$ nanotube arrays-based gate electrodes. Sens Actuators B Chem. 2015;208: $457-463$.
23. Wang Y, Chen J, Zhou CP, et al. A novel self-cleaning, non-enzymatic glucose sensor working under a very low applied potential based on a Pt nanoparticle-decorated $\mathrm{TiO}_{2}$ nanotube array electrode. Electrochim Acta. 2014;115:269-276.

24. Park J, Bauer S, Schlegel KA, Neukam FW, von der Mark K, Schmuki P. $\mathrm{TiO}_{2}$ nanotube surfaces: $15 \mathrm{~nm}$ - an optimal length scale of surface topography for cell adhesion and differentiation. Small. 2009;5: 666-671.

25. Yang H, Qin XF, Tian A, Zhang D, Xue X, Wu A. Nano size effects of $\mathrm{TiO}_{2}$ nanotube array on the glioma cells behavior. Int J Mol Sci. 2013; $14: 244-254$.

26. Von Der Mark K, Bauer S, Park J, Schmuki P. Another look at "stem cell fate dictated solely by altered nanotube dimension". Proc Natl Acad Sci U S A. 2009;106:E60.

27. Bondy ML, Scheurer ME, Malmer B, et al; Brain Tumor Epidemiology Consortium. Brain Tumor Epidemiology: Consensus from the Brain Tumor Epidemiology Consortium. Cancer. 2008;113:1953-1968.

28. Furnari FB, Fenton T, Bachoo RM, et al. Malignant astrocytic glioma: genetics, biology, and paths to treatment. Gene Dev. 2007;21: 2683-2710.

29. Wang W, Zhao L, Ma Q, Wang Q, Chu PK, Zhang Y. The role of the Wnt/ $\beta$-catenin pathway in the effect of implant topography on MG63 differentiation. Biomaterials. 2012;33:7993-8002.

30. Wang DA, Liu Y, Yu B, et al. $\mathrm{TiO}_{2}$ nanotubes with tunable morphology, diameter, and length: synthesis and photo-electrical/catalytic performance. Chem Mater. 2009;21:1198-1206.

31. Schroeder BR, Ghare MI, Bhattacharya C, et al. The disaccharide moiety of bleomycin facilitates uptake by cancer cells. J Am Chem Soc. 2014; 136:13641-13656.

32. Fu CY, Xia RL, Zhang TF, et al. Hemokinin-1(4-11)-induced analgesia selectively up-regulates $\delta$-opioid receptor expression in mice. PLoS One. 2014;9:e90446.

33. Rajnicek AM, McCaig CD. Guidance of CNS growth cones by substratum grooves and ridges: effects of inhibitors of the cytoskeleton, calcium channels and signal transduction pathways. J Cell Sci. 1997; 110:2915-2924.

34. García AJ. Get a grip: integrins in cell-biomaterial interactions. Biomaterials. 2005;26:7525-7529.

35. Bauer S, Park J, Faltenbacher J, Song YY, von der Mark K, Schmuki P. Size selective behavior of mesenchymal stem cells on $\mathrm{ZrO} 2$ and $\mathrm{TiO}_{2}$ nanotube arrays. Integr Biol (Camb). 2009;1:525-532.

36. Rosso F, Marino G, Giordano A, Barbarisi M, Parmeggiani D, Barbarisi A. Smart materials as scaffolds for tissue engineering. J Cell Physiol. 2005;203:465-470.

37. Li S, Bhatia S, Hu YL, et al. Effects of morphological patterning on endothelial cell migration. Biorheology. 2001;38:101-108.

38. Yilmaz M, Christofori G. EMT, the cytoskeleton, and cancer cell invasion. Cancer Metast Rev. 2009;28:15-33.

39. Yeh WL, Lu DY, Liou HC, Fu WM. A forward loop between glioma and microglia: glioma-derived extracellular matrix-activated microglia secrete IL-18 to enhance the migration of glioma cells. J Cell Physiol. 2012;227:558-568.

40. Uhm JH, Dooley NP, Kyritsis AP, Rao JS, Gladson CL. Vitronectin, a glioma-derived extracellular matrix protein, protects tumor cells from apoptotic death. Clin Cancer Res. 1999;5:1587-1594.

41. Nikolovski J, Mooney DJ. Smooth muscle cell adhesion to tissue engineering scaffolds. Biomaterials. 2000;21:2025-2032.

42. Mazare A, Dilea M, Ionita D, Titorencu I, Trusca V, Vasile E. Changing bioperformance of $\mathrm{TiO}_{2}$ amorphous nanotubes as an effect of inducing crystallinity. Bioelectrochemistry. 2012;87:124-131.

43. Bai Y, Park S, Park HH, et al. The effect of annealing temperatures on surface properties, hydroxyapatite growth and cell behaviors of $\mathrm{TiO}_{2}$ nanotubes. Surf Interface Anal. 2011;43:998-1005.

44. Palazzo A, Ackerman B, Gundersen GG. Cell biology: tubulin acetylation and cell motility. Nature. 2003;421:230.

45. Takagi J, Petre BM, Walz T, Springer TA. Global conformational rearrangements in integrin extracellular domains in outside-in and inside-out signaling. Cell. 2002;110:599-611. 
46. Peng RJ, Jiang B, Ma JR, et al. Forced downregulation of RACK1 inhibits glioma development by suppressing Src/Akt signaling activity. Oncol Rep. 2013;30:2195-2202.

47. Shi L, Chen J, Yang J, Pan T, Zhang S, Wang Z. MiR-21 protected human glioblastoma U87MG cells from chemotherapeutic drug temozolomide induced apoptosis by decreasing $\mathrm{Bax} / \mathrm{Bcl}-2$ ratio and caspase- 3 activity. Brain Res. 2010;1352:255-264.

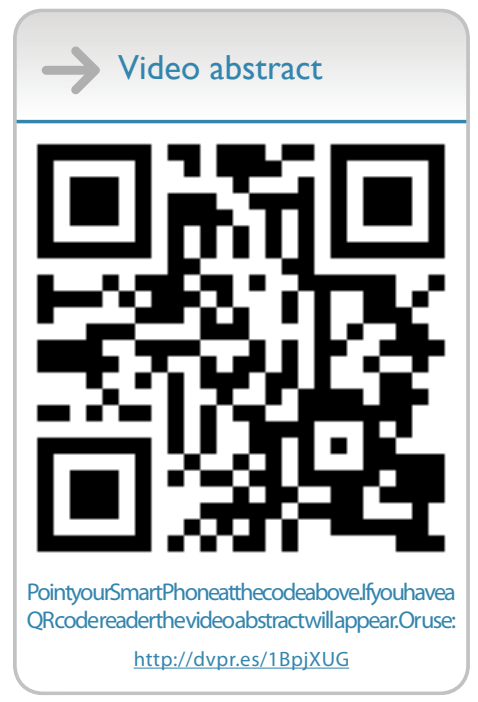

48. Tsurushima H, Yuan X, Dillehay LE, Leong KW. Radio-responsive gene therapy for malignant glioma cells without the radiosensitive promoter: Caspase-3 gene therapy combined with radiation. Cancer Lett. 2007;246:318-323. 


\section{Supplementary materials}
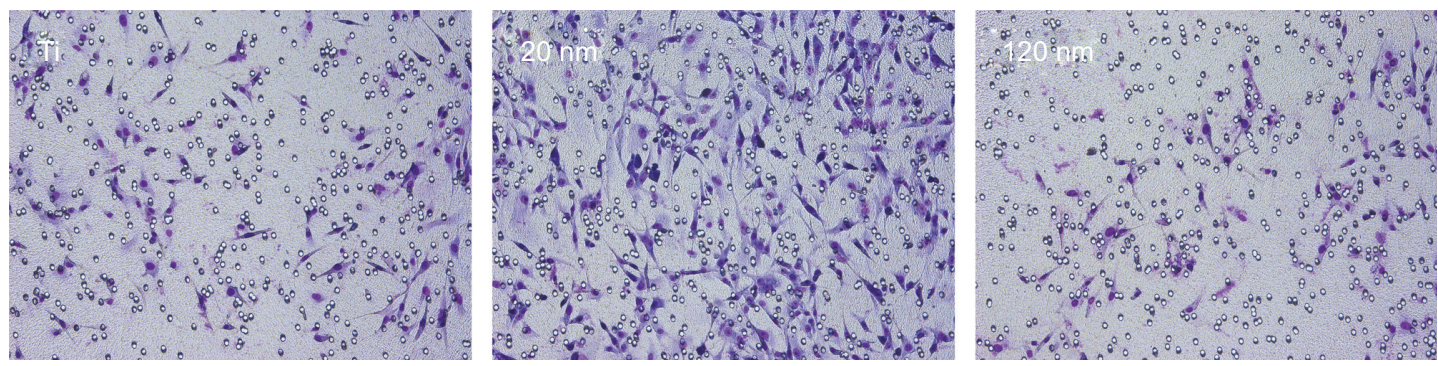

Figure SI Images of the transwell assay of U87 cells cultured on the nanotubes without annealing, the smooth surface of titanium was control. Abbreviation: $\mathrm{Ti}$, titanium.
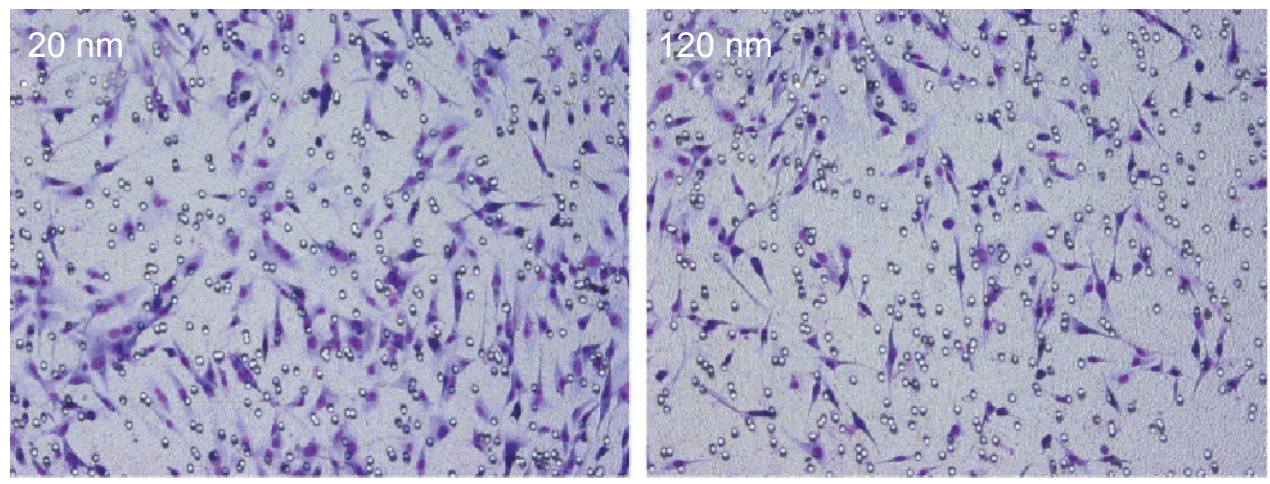

Figure S2 Image of the transwell assay of U87 cells cultured on the nanotubes with annealing.
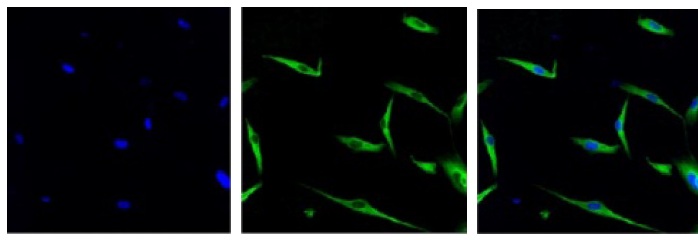

$\mathrm{Ti}$
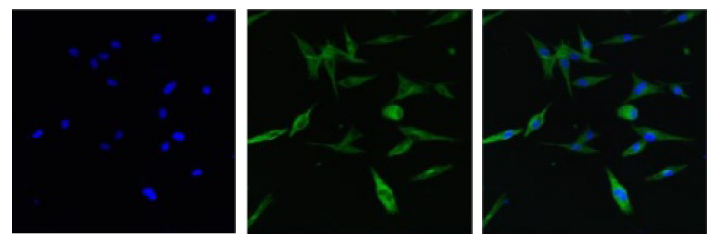

$20 \mathrm{~nm}$ without annealing
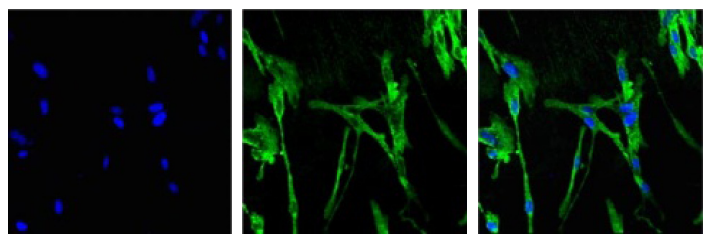

$120 \mathrm{~nm}$ without annealing

Figure S3 Immunofluorescence of acetylated $\alpha$-tubulin expression in U87 cells cultured on nanotubes including the image of nuclear staining, the nanotubes were without annealing and the smooth surface of titanium was control. Abbreviation: $\mathrm{Ti}$, titanium. 

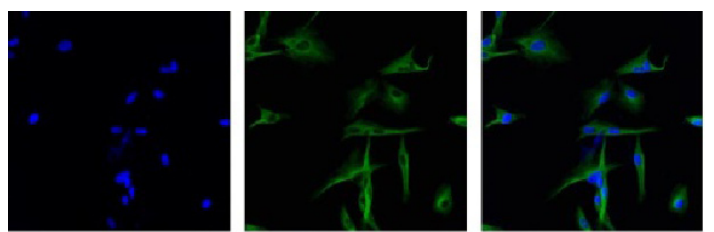

$20 \mathrm{~nm}$ with annealing
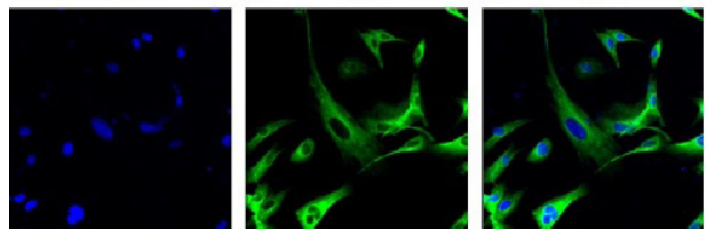

$120 \mathrm{~nm}$ with annealing

Figure S4 Immunofluorescence of acetylated $\alpha$-tubulin expression in U87 cells cultured on nanotubes including the image of nuclear staining, the nanotubes were annealed.
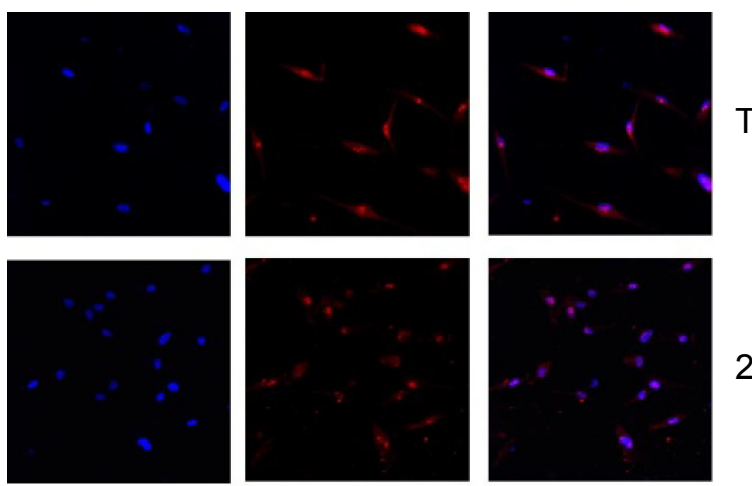

$20 \mathrm{~nm}$ without annealing
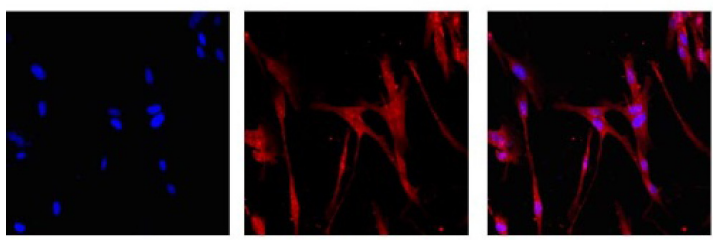

$120 \mathrm{~nm}$ without annealing

Figure S5 Immunofluorescence of caspase-3 expression in U87 cells cultured on nanotubes including the image of nuclear staining, the nanotubes were without annealing and the smooth surface of titanium was control.

Abbreviation: $\mathrm{Ti}$, titanium.
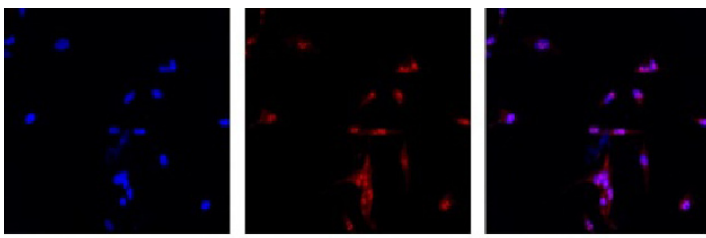

$20 \mathrm{~nm}$ with annealing
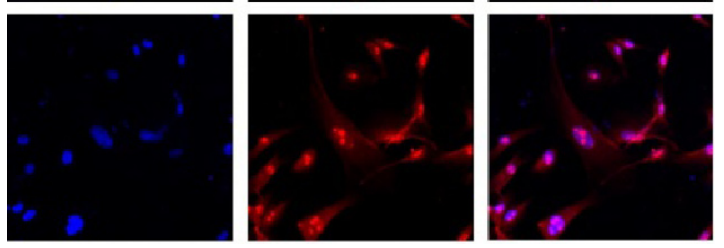

$120 \mathrm{~nm}$ with annealing

Figure $\mathbf{S} 6$ Immunofluorescence of caspase-3 expression in U87 cells cultured on nanotubes including the image of nuclear staining, the nanotubes were annealed. 

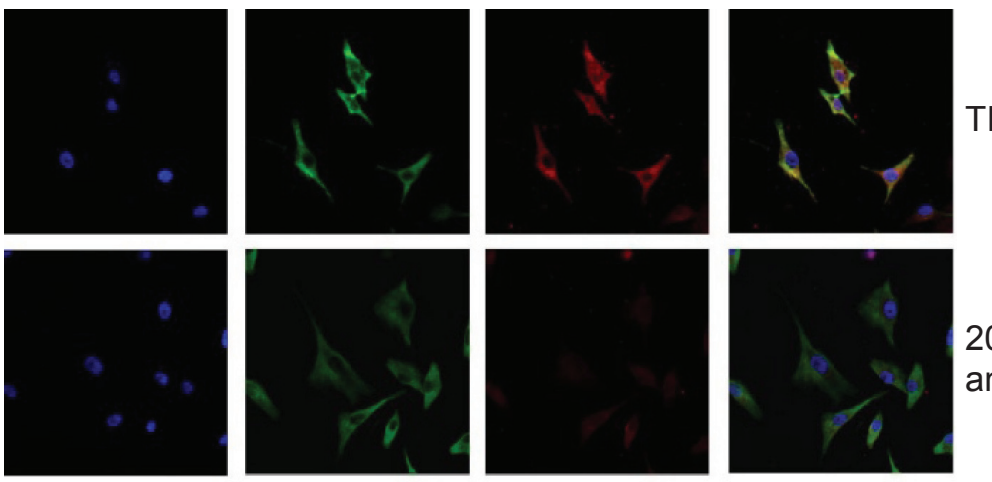

$20 \mathrm{~nm}$ without annealing
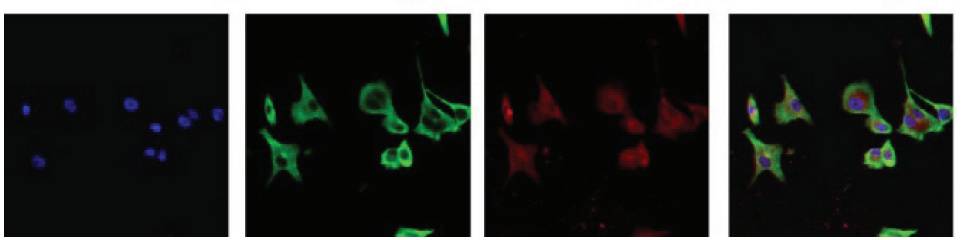

$120 \mathrm{~nm}$ without annealing

Figure S7 Double staining of caspase- 3 and acetylated $\alpha$-tubulin expression in MG-63 cells cultured on nanotubes with different diameters including the image of nuclear staining, the nanotubes were without annealing and the smooth surface of titanium was control. Abbreviation: $\mathrm{Ti}$, titanium


\section{$20 \mathrm{~nm}$ with}

annealing
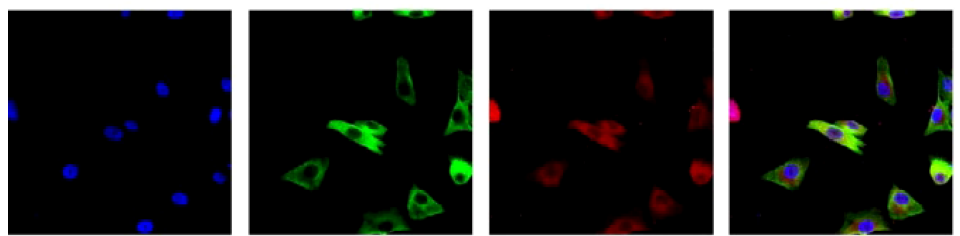

$120 \mathrm{~nm}$ with

annealing

Figure S8 Double staining of caspase-3 and acetylated $\alpha$-tubulin expression in MG-63 cells cultured on nanotubes with different diameters including the image of nuclear staining, the nanotubes were annealed.

International Journal of Nanomedicine

\section{Publish your work in this journal}

The International Journal of Nanomedicine is an international, peerreviewed journal focusing on the application of nanotechnology in diagnostics, therapeutics, and drug delivery systems throughou the biomedical field. This journal is indexed on PubMed Central, MedLine, CAS, SciSearch $\AA$, Current Contents ${ }^{\circledR} /$ Clinical Medicine,

\section{Dovepress}

Journal Citation Reports/Science Edition, EMBase, Scopus and the Elsevier Bibliographic databases. The manuscript management system is completely online and includes a very quick and fair peer-review system, which is all easy to use. Visit http://www.dovepress.com/ testimonials.php to read real quotes from published authors.

\footnotetext{
Submit your manuscript here: http://www.dovepress.com/international-journal-of-nanomedicine-journal
} 